\title{
SOSIALISASI DAN PELATIHAN PENGENDALIAN ANTRAKNOSA PADA TANAMAN CABAI MENGGUNAKAN KHAMIR SEBAGAI KOMPONEN PENGENDALIAN RAMAH LINGKUNGAN
}

\author{
Sri Hartati, Endah Yulia, dan Luciana Djaya \\ Program Studi Agroteknologi, Fakultas Pertanian, Universitas Padjadjaran \\ E-mail: s.hartati@unpad.ac.id
}

\begin{abstract}
ABSTRAK. Cabai merupakan salah satu komoditas yang memiliki nilai ekonomi tinggi. Akan tetapi, produksi cabai sering terhambat oleh adanya penyakit salah satunya adalah antraknosa. Pengendalian yang umum dilakukan untuk mengendalikan penyakit antraknosa adalah dengan fungisida sintetik. Untuk mengatasi permasalahan tersebut perlu dilakukan kegiatan penyuluhan dan pelatihan pengendalian antraknosa secara ramah lingkungan. Kegiatan ini dilakukan di Desa Cilayung yang merupakan salah satu desa di Kecamatan Jatinangor yang memiliki potensi pertanian cukup tinggi. Tujuan kegiatan ini untuk mensosialisasikan pengendalian ramah lingkungan dan menerapkan salah satu cara pengendalian tersebut dengan menggunakan khamir. Metode yang dilakukan dalam kegiatan ini diantaranya survei lokasi, sosialisasi, wawancara, penyuluhan, dan pelatihan. Hasil kegiatan yang sudah dilakukan adalah (1) penyuluhan tentang penyebab penyakit tanaman secara umum dan penyakit antraknosa pada cabai, dampak negatif pestisida sintetik yang berlebihan, dan pengendalian ramah lingkungan, (2) pelatihan penggunaan mikrob antagonis berupa khamir Rhodotorula minuta, (3) hasil survei dan wawancara mendapatkan informasi mengenai pengetahuan dan pemahaman petani dan ibu-ibu PKK tentang cara pengendalian organisme pengganggu tanaman (OPT). Setelah mengikuti kegiatan ini terjadi peningkatan pengetahuan, pemahaman, dan daya tarik petani dan ibu-ibu PKK untuk melakukan pengendalian OPT dengan ramah lingkungan.
\end{abstract}

Kata kunci: Desa Cilayung; mikrob antagonis; pengendalian OPT; penyuluhan

\section{SOCIALIZATION AND TRAINING ON THE ENVIRONMENTAL-FRIENDLY CONTROL OF CHILLI ANTHRACNOSE BY USING YEASTS}

\begin{abstract}
Chilli is an agricultural commodity with high economical value. However, the production cannot reach its potential because of anthracnose disease. The disease is usually controlled chemically by using synthetic fungicides. To reduce the use of synthetic pesticides, it is necessary to organize a counselling and training for the farmers about environmental-friendly methods in controlling antrhracnose on red chilli. The counselling and training was carried out at Desa Cilayung, Kecamatan Jatinangor which has a high potency in agriculture. The objective of this activity was to socialize an environmentally safe anthracnose control methods by using yeast. The methods were site survey, socialization, interview, counselling, and training. The activities that had been done were (1) counselling about the causes of plant disease, anthracnose on chilli, negative impact of the use of synthetic pesticides, and environmentally friendly control methods, (2) training about the use of antagonistic yeast (Rhodotorula minuta), (3) The results of the survey and interview were information about the knowledge and skills of the farmers and PKK ladies on how to control plant pests. After doing these activities, the knowledge, understanding, and interest of the farmers and PKK ladies to do environmentally safe pest control methods were increased.
\end{abstract}

Key words: Desa Cilayung; antagonistic microbe; pest control; counselling

\section{PENDAHULUAN}

Cabai merah (Capsicum annuum L.) merupakan salah satu komoditas hortikultura utama yang mempunyai nilai ekonomi tinggi dan merupakan komoditas unggulan lokal di Jawa Barat. Akan tetapi, produktivitas cabai sampai saat ini masih dibawah potensi produksinya. Berbagai faktor dapat menjadi penyebab rendahnya produksi cabai, salah satunya adalah gangguan penyakit. Penyakit antraknosa merupakan salah satu penyakit utama yang dapat menyebabkan turunnya produksi cabai. Di Indonesia, kehilangan hasil akibat penyakit ini mencapai 50-100\% (Hariati, 2007). Penyakit antraknosa dapat disebabkan oleh jamur Colletotrichum capsici, Colletotrichum acutatum, dan Colletotrichum gloeosporioides (AVRDC, 2004). Jamur C. acutatum dapat menyebabkan kehilangan hasil yang signifikan pada tanaman penghasil buah dan sayuran (Staňková et al., 2011).

Hingga saat ini upaya mengatasi serangan penyakit antraknosa masih sangat tergantung pada penggunaan fungisida kimia sintetik. Akan tetapi, pestisida kimia sintetik menimbulkan dampak negatif terhadap lingkungan seperti terjadinya resistensi patogen terhadap fungisida tersebut, dan dapat merusak lingkungan (Kishi et al., 1995).

Disamping dampak negatif fungisida kimia sintetik terhadap lingkungan, saat ini pengetahuan masyarakat tentang dampak residu pestisida kimia sintetik pada produk pertanian semakin meningkat. Hal ini menyebabkan bertambahnya tuntutan terhadap produk pertanian yang bebas pestisida kimia sintetik. Salah satu cara pengendalian antraknosa yang ramah lingkungan dapat dilakukan dengan menggunakan mikrob antagonis atau agens biokontrol yaitu khamir. Beberapa khamir telah dilaporkan mampu mengendalikan penyakit antraknosa pada cabai diantaranya Pichia guilliermondii, Candida musae, Issatchenkia orientalis dan Candida quercitrusa (Chanchaichaovivat et al., 2007).

Agens biokontrol memiliki empat mekanisme utama dalam mengendalikan penyakit yaitu kompetisi, hiperparasitisme, antibiosis dan induksi resistensi (Sharma et al., 2009). Menurut Nunes (2012) khamir memiliki 
mekanisme antagonisme berupa kompetisi nutrisi dan ruang, hiperparasitisme dan produksi enzim litik serta induksi resistensi sehingga mampu mengendalikan beberapa patogen tanaman.

Eksplorasi khamir telah dilakukan dari tanaman cabai pada tahun 2012 (Hartati, 2016). Salah satu spesies khamir yang dihasilkan dalam penelitian tersebut adalah Rhodotorula minuta. Khamir $R$. minuta telah diuji kemampuannya sebagai agens antagonis penyebab penyakit antraknosa Colletotrichum acutatum pada cabai baik melalui mekanisme secara langsung maupun secara tidak langsung dengan induksi resistensi.

Desa Cilayung merupakan salah satu desa di Kecamatan Jatinangor yang mempunyai potensi dalam bidang pertanian. Pertanian merupakan kegiatan rutin yang dilakukan sebagian besar penduduk di Desa Cilayung (Thoriq \& Fauzan, 2017). Salah satu komoditas pertanian yang ditanam di desa ini adalah cabai. Namun, berbagai kendala ditemui dalam budidaya cabai di Desa Cilayung, salah satunya serangan patogen antraknosa. Permasalahan penyakit antraknosa pada cabai mendorong semakin meningkatnya penggunaan fungisida kimia sintetik oleh petani. Bahkan pada saat ini, penanaman cabai di Desa Cilayung semakin berkurang. Oleh karena itu, perlu dilakukan kegiatan pengabdian kepada masyarakat (PKM) yaitu penyuluhan dan pelatihan di Desa Cilayung mengenai pengendalian penyakit antraknosa pada cabai yang ramah lingkungan. Kegiatan PKM ini melibatkan petani dan ibu-ibu PKK. Tujuan dari dilaksanakannya kegiatan PKM ini adalah untuk menerapkan salah satu cara pengendalian ramah lingkungan dengan menggunakan khamir antagonis terhadap penyakit antraknosa pada cabai, meningkatkan pemahaman petani di Desa Cilayung tentang pentingnya melakukan pengendalian penyakit tanaman secara ramah lingkungan, dan meningkatkan kesadaran petani akan bahaya penggunaan pestisida kimia sintetik yang berlebihan.

\section{METODE}

Kegiatan utama dalam PKM ini adalah (1) penyuluhan tentang dampak negatif penggunaan pestisida kimia sintetik, penyakit tumbuhan dan komponen pengendalian penyakit yang ramah lingkungan, cara pengendalian penyakit antraknosa secara ramah lingkungan dan penggunaan khamir sebagai salah satu cara pengendalian antraknosa, (2) pelatihan tentang pengendalian penyakit antraknosa menggunakan khamir antagonis. Kegiatan utama tersebut didukung dengan kegiatan pendukung yaitu, (1) survei lokasi, (2) sosialisasi kegiatan kepada kepala desa, aparat desa, dan ketua kelompok tani, (3) wawancara kepada petani dan ibuibu PKK sebanyak 60 responden. Responden dipilih berdasarkan usia. Responden yang dipilih yaitu yang berusia produktif baik petani maupun ibu -ibu PKK yaitu berkisar antara 30-60 tahun. Alat ukur yang digunakan untuk mengukur tingkat keberhasilan penyuluhan dan pelatihan ini adalah hasil wawancara dengan menggunakan kuosioner sebelum dan setelah kegiatan dilakukan.

\section{HASIL DAN PEMBAHASAN}

Berdasarkan hasil wawancara awal yang telah dilakukan diperoleh banyak informasi mengenai kondisi petani dan pengetahuannya tentang cara pengendalian penyakit maupun hama pada tanaman. Responden merupakan petani dan ibu-ibu PKK yang sebagian besar berumur antara 30-60 tahun. Akan tetapi, menurut Thoriq \& Fauzan (2017) hampir seluruh pelaku sektor pertanian di Desa Cilayung telah berusia lanjut. Jenjang pendidikan responden terbanyak berpendidikan $\mathrm{SD}$, dan pekerjaan baik utama maupun sampingan yang dominan sebagai petani. Informasi awal yang didapatkan berdasarkan hasil wawancara sebelum dilakukan kegiatan adalah sebagai berikut (1) pengetahuan responden terhadap patogen penyebab penyakit tanaman masih kurang, sebagian responden mengetahui adanya penyakit pada tanaman tetapi tidak mengetahui penyebabnya, (2) sebagian responden mengetahui penyakit antraknosa pada cabai dengan nama penyakit patek, (3) seluruh responden mengendalikan penyakit antraknosa dengan fungisida sintetik, (4) sebagian responden mengetahui bahwa pestisida sintetik berbahaya tetapi mereka tidak mengetahui dampak negatif pestisida sintetik terhadap lingkungan, (5) sebagian besar dari responden belum mengetahui cara pengendalian dengan mikrob dan seluruh responden belum pernah melakukan pengendalian dengan menggunakan mikrob, (6) berbeda dengan pengetahuan responden tentang pengendalian mikrob, sebagian responden telah mengetahui cara pengendalian dengan pestisida nabati dan pernah menggunakan pengendalian dengan pestisida nabati, (7) sebagian besar responden belum mengenal pengendalian penyakit tanaman yang ramah lingkungan. Akan tetapi, sebagian besar responden bersedia mencoba menggunakan pengendalian ramah lingkungan untuk mengendalikan hama dan penyakit pada tanamannya.

Untuk mengatasi permasalahan rendahnya pengetahuan petani tentang penyebab penyakit tanaman, dampak negatif penggunaan pestisida kimia sintetik berlebihan, dan pengendalian yang ramah lingkungan khususnya dalam mengendalikan penyakit antraknosa pada cabai, maka tim pelaksana PKM berupaya untuk memfasilitasi dan bekerjasama dengan petani dan ibuibu PKK. Kegiatan PKM tersebut dilakukan melalui penyuluhan dan pelatihan untuk memberikan pemahaman dan pengetahuan mengenai penyebab penyakit tanaman secara umum dan penyakit antraknosa pada cabai, perbedaan hama dan penyakit tanaman, dampak negatif pestisida sintetik yang berlebihan, dan pengendalian ramah lingkungan, serta penggunaan mikrob berupa khamir untuk mengendalikan penyakit antraknosa pada 
cabai. Hal ini diharapkan petani dan ibu-ibu PKK dapat menerapkan teknologi pengendalian penyakit tanaman yang ramah lingkungan dan dihasilkannya produk cabai yang sehat. Kegiatan penyuluhan dilaksanakan di Kantor Desa Cilayung sebanyak tiga kali pertemuan.

Kegiatan penyuluhan dengan materi pengenalan penyakit dan penyebabnya merupakan materi yang sangat penting untuk memberikan pengetahuan kepada petani perbedaan antara hama dan penyakit tanaman. Materi tersebut sangat berguna untuk mengidentifikasi penyebab gangguan pada tanaman yang pada akhirnya akan menentukan cara pengendalian yang harus dilakukan. Kesalahan dalam identifikai penyebab gangguan pada tanaman akan menyebabkan kesalahan dalam melakukan pengendaliannya. Pada kenyataannya, hampir seluruh petani melakukan pengendalian terhadap organisme pengganggu tanaman (OPT) di pertanamannya dengan menggunakan pestisida sintetik, meskipun sebagian dari petani dan ibu-ibu PKK mengetahui bahaya penggunaan pestisida sintetik secara berlebihan. Akan tetapi, karena terdorong oleh permasalahan OPT yang selalu dihadapinya maka petani kembali menggunakan pestisida sintetik tanpa memperhatikan target dari OPT yang akan dikendalikannya. Petani menganggap bahwa cara pengendalian dengan menggunakan pestisida sintetik lebih ampuh dibandingkan cara pengendalian lain. Hal ini disebabkan hasil pengendalian sintetik lebih cepat terlihat. Berdasarkan hasil kegiatan penyuluhan tersebut maka perlu dilakukan penyuluhan secara rutin agar petani betul-betul mau mengaplikasikan cara pengendalian yang ramah lingkungan. Apabila melihat antusiasme petani dan ibu-ibu PKK dalam mengikuti kegiatan penyuluhan dan berdasarkan hasil wawancara, diketahui bahwa petani dan ibu-ibu PKK bersedia mencoba cara pengendalian yang ramah lingkungan untuk mengendalikan penyakit antraknosa pada cabai dan penyakit tanaman lainnya

Kegiatan PKM lain yang dilakukan untuk mengatasi permasalahan OPT yang dihadapi oleh petani di Desa Cilayung adalah pelatihan. Adapun materi pelatihan kepada petani yang dilakukan untuk memperkenalkan salah satu komponen pengendalian penyakit antrknosa pada cabai yang ramah lingkungan yaitu penggunaan mikrob antagonis berupa khamir. Khamir yang digunakan adalah Rhodotorula minuta yaitu merupakan salah satu khamir yang didapatkan dari daun dan buah cabai. Khamir $R$. minuta tersebut telah diuji kemampuannya dalam mengendalikan penyakit antraknosa pada cabai yang disebabkan oleh Colletotrichum acutatum. Khamir $R$. minuta mampu mengendalikan penyakit antraknosa pada buah cabai pada skala semi in-vivo sebesar 90,17\% dengan mekanisme pembentukan senyawa volatil, hiperparasitisme, dan pembentukan enzim ACC deaminase (Hartati, 2016). Khamir R. minuta juga mampu mengendalikan penyakit antraknosa pada cabai dengan mekanisme induksi resistensi melalui peningkatan aktivitas enzim peroksidase, phenylalanin ammonia lyase
(PAL), dan asam salisilat yang berperan dalam ketahanan tanaman terhadap patogen (Hartati dkk., 2017).

Pelatihan penggunaan mikrob antagonis berupa khamir $R$. minuta untuk mengendalikan penyakit antraknosa dilakukan di kantor Desa Cilayung yang dihadiri oleh petani dan ibu-ibu PKK yang sebelumnya telah mengikuti kegiatan penyuluhan.

diperlihatkan koloni $R$. minuta dalam media biakan potato dextrose agar (PDA), didemonstrasikan cara pembuatan suspensi khamir dengan kerapatan sel $10^{8} \mathrm{sel} /$ $\mathrm{ml}$, perlakuan suspensi khamir pada benih cabai, pemeraman benih cabai berperlakuan, dan penanaman benih cabai yang telah diberi perlakuan khamir pada media tanam dalam polibag. Benih cabai berperlakuan khamir yang telah ditanam dalam polibag selanjutnya dibagikan kepada masing-masing peserta pelatihan untuk dipelihara. Pertanaman cabai berperlakuan khamir yang telah dipelihara oleh peserta pelatihan.

Berdasarkan pengamatan dan laporan dari peserta pelatihan diketahui bahwa pertanaman cabai yang mereka pelihara tumbuh dengan baik tanpa adanya gejala penyakit antraknosa. Pertumbuhan tanaman yang baik tersebut diperlihatkan hingga tanaman menghasilkan buah dan panen. Perlakuan perendaman benih cabai dalam suspensi khamir $R$. minuta memungkinkan terjadinya induksi resistensi pada tanaman cabai yang tumbuh. Pengaruh khamir $R$. minuta tersebut terhadap terjadinya induksi resistensi dapat berupa peningkatan enzimenzim yang berhubungan dengan ketahanan tanaman seperti peroksidase dan PAL (Hartati dkk., 2017). Peran khamir dalam induksi resistensi pada buah-buahan melalui pembentukan elisitor telah dilaporkan. Beberapa penelitian melaporkan bahwa khamir dapat menginduksi buah-buahan dan tanaman dengan menghasilkan $P R$ proteins seperti kitinase, $\beta$-1,3-glucanase, peroksidase (Ippolito et al., 2000), PAL, akumulasi fitoaleksin, dan 1,3-endoglucanase (Droby et al., 2002; Nantawanit et al., 2010). Mengingat patogen penyebab antraknosa dapat terbawa benih, dapat menyerang bibit cabai, daun, batang, dan buah, maka perlakuan khamir $R$. minuta dengan perendaman benih untuk terjadinya mekanisme induksi resistensi pada pelatihan ini sangat sesuai. Hasil penanaman cabai tersebut diharapkan dapat menarik minat petani dan ibu-ibu PKK untuk mulai menggunakan pengendalian dengan mikrob dalam mengendalikan penyakit pada tanamannya. Hal ini diharapkan sedikit demi sedikit ketergantungan petani pada pestisida sintetik dapat berkurang.

Hasil wawancara akhir menunjukkan bahwa setelah dilakukan kegiatan penyuluhan dan pelatihan, pengetahuan dan pemahaman petani dan ibu-ibu PKK terhadap dampak negatif pestisida sintetik dan pentingnya pengendalian penyakit secara ramah lingkungan menjadi meningkat (Gambar 6). Peningkatan pengetahuan dan pemahaman petani dari hasil penyuluhan dan pelatihan ini diharapkan dapat diterapkan dalam skala luas di 
lapangan dan petani dapat kembali menanam cabai untuk menghasilkan produk cabai yang sehat, serta meningkatkan pendapatannya. Dengan meningkatnya kesadaran masyarakat akan bahaya dan dampak negatif pestisida sintetik, juga diharapkan dapat mengubah sikap petani terhadap cara pengendalian OPT pada tanaman yang dibudidayakan. Keberhasilan program penyuluhan dan pelatihan dalam PKM ini didukung oleh antusias yang tinggi dan respon yang sangat baik dari petani dan ibu-ibu PKK di Desa Cilayung, Kecamatan Jatinangor. Dukungan dan respon yang sangat baik juga diperoleh dari kepala desa, aparat desa, dan ketua kelompok tani dan PKK. Dukungan tersebut berupa pemberian ijin pelaksanaan PKM, penyediaan tempat dalam pelaksanaan penyuluhan dan pelatihan, sosialisasi kegiatan yang akan dilaksanakan dalam PKM, serta pengumpulan peserta penyuluhan dan pelatihan dari petani maupun ibu-ibu PKK.

\section{SIMPULAN}

Setelah kegiatan PKM dilaksanakan terjadi peningkatan pengetahuan, pemahaman, dan daya tarik petani dan ibu-ibu PKK untuk melakukan pengendalian penyakit antraknosa pada cabai khususnya dan OPT pada umumnya dengan menggunakan mikrob seperti khamir dan pengendalian lain yang ramah lingkungan. Dukungan dan keterlibatan aparat desa serta masyarakat dalam kegiatan ini menunjang keberhasilan pelaksanaan kegiatan penyuluhan dan pelatihan yang dilakukan.

\section{UCAPAN TERIMAKASIH}

Terima kasih disampaikan kepada Direktorat Riset dan Pengabdian Kepada Masyarakat dan Inovasi Universitas Padjadjaran yang telah mendanai kegiatan ini melalui Pengabdian Kepada Masyarakat Program Hibah Internal Universitas Tahun Anggaran 2018.

\section{DAFTAR PUSTAKA}

AVRDC (Asian Vegetable Research Development and Center). (2004). Evaluation of Phenotypic and Molecular Criteria for the Identification of Colletotrichum Species Causing Pepper Anthracnose in Taiwan, p.92-93. In Warwick Easdown \& Thomas Kalb (ed.), AVRDC Report. AVRDC, Shanhua, Taiwan.

Chanchaichaovivat, A., Ruenwongsa, P., \& Panijpan, B. (2007). Screening and Identification of Yeast Strains from Fruits and Vegetables: Potential for Biological Control of Postharvest Chilli Anthracnose (Colletotrichum capsici). Biological Control 42: 326-335.
Droby, S., Vinokur, V., Weiss, B., Cohen, L., Daus, A., Goldschmidt, E.E., \& Porat, R. (2002). Induction of resistance to Penicillium digitatum in grapefruit by the yeast biocontrol agent Candida oleophila. Phytopathology. 92:393-399.

Hariati, N. (2007). Analisis keanekaragaman 23 genotipe cabai (Capsicum sp.) berdasarkan penampakan fenotipik serta ketahanannya terhadap penyakit antraknosa (Colletotrichum sp). Skripsi, Fakultas Pertanian. Bogor: Institut Pertanian Bogor.

Hartati, S. (2016). Khamir Sebagai Agens Biokontrol Antraknosa (Colletotrichum acutatum Simmonds, J.H.) Pada Cabai Pascapanen. Disertasi, Fakultas Pertanian. Bogor: Sekolah Pascasarjana Institut Pertanian Bogor.

Hartati, S., Meliansyah, R., \& Djaya, L. (2017). Khamir sebagai Penginduksi Resistensi Tanaman Cabai untuk Mengendalikan Penyakit Antraknosa dan Kuning Keriting pada Caiab (Capsicum annuum L.). Laporan Penelitian, Fakultas Pertanian. Jatinangor: Universitas Padjadjaran.

Ippolito, A., El-Ghaouth, A., Wilson, C.L., Wisniewski, M. (2000). Control of postharvest decay of apple fruit by Aureobasidium pullulans and induction of defense responses. Postharvest Biology Technology. 19:265-272.

Kishi M, Hirschhorn, N., Djajadisastra, M., Satterlee, L.N., Strowman, S., \& Dilts, R. (1995). Relationship of pesticide spraying to signs and symptoms in Indonesian farmers. Scandinavian Journal of Work Environment \& Health 21:124-133.

Nantawanit, N., Chanchaichaovivat, A., Panijpa,n B., $\&$ Ruenwongsa, P. (2010). Induction of defense response against Colletotrichum capsici in chili fruit by the yeast Pichia guilliermondii strain R13. Biological Control. 52:145-52.

Nunes, C.A. (2012). Biological control of postharvest diseases of fruit. European Journal of Plant Pathology. 133:181-96.

Sharma, R.R., Singh, D., \& Singh, R. (2009). Biological control of postharvest diseases of fruits and vegetables by microbial antagonists. Biological Control. 50: 205-221.

Stankova, B., Vichova, J. \& Pokorny, R. (2011). Virulence of Colletotrichum acutatum isolates to several host plants. Acta Universitatis Agriculturae et Silviculturae Mendelianae Brunensis. 59, (3),161-170.

Thoriq, A. \& Fauzan, I. 2017. Edukasi teknologi pertanian untuk anak usia dini di Desa Cilayung, Kecamatan Jatinangor. 6, (1): 18-20. 